\title{
THE RENAL RESPONSE TO INTRAVENOUS INJECTION OF SODIUM CHLORIDE SOLUTIONS IN MAN ${ }^{1}$
}

\author{
BY BETTY CRAWFORD AND HENRY LUDEMANN 2 \\ (From the Department of Surgery, New York University College of Medicine and the Third \\ Surgical Division, Bellevue Hospital, New York, N. Y.)
}

(Submitted for publication September 5, 1950; accepted August 27, 1951)

The administration of isotonic saline solution to dogs in quantities equal to one-half or more of the volume of extracellular fluid leads to a prompt increase in glomerular filtration rate and the excretion of sodium and chloride. Although factors possibly influencing tubular reabsorptive activity, such as the adrenal and neurohypophysial hormones, are not as yet amenable to quantitative study, the general correlation between filtration rate and sodium excretion in the dog has led many investigators to believe that changes in glomerular activity constitute one of the most important mechanisms in the maintenance of salt and water balance in this animal (1-5). So effective is this renal response that, with other adjunctival mechanisms, dogs may be maintained on diets containing $4 \mathrm{gm}$. of salt per $\mathrm{kg}$. per day (corresponding to $280 \mathrm{gm}$. per day in a $70 \mathrm{~kg}$. man) without gain in weight or apparent disturbance in salt and water balance (5).

An extensive literature is available (6) on the excretion of sodium, chloride and water in patients receiving saline infusions, but in great part the information contained therein is merely descriptive of the fact of diuresis (or absence of diuresis) and is not correlated with the measurable physiological mechanisms concerned in the excretion of sodium and water. No information is available on the effect of saline solutions on renal function in man, and the present study. was undertaken to obtain information, comparable to that available on the $\mathrm{dog}$, on the changes in filtration rate, renal blood flow and electrolyte excretion after the rapid administration of saline infusions.

\footnotetext{
1 Aided by grants from the National Institutes of Health, Public Health Service, and the Commonwealth Fund.

2 Postdoctorate Research Fellow, National Institutes of Health, U. S. Public Health Service.
}

\section{METHODS}

Our observations were made on 35 ambulatory patients, ranging in age from 19 to 75 years, who had been hospitalized for relatively benign conditions, who had not undergone surgery, and who were ready for discharge. None presented clinical evidence of cardiac or renal disease. All were afebrile and maintained on a regular ward diet.

The patients drank a liter of water the night before observation. This water was consumed in divided doses at the patients' convenience. After a light breakfast, they were brought to the research unit for renal function studies at about 8:00 a.m. After appropriate priming injections, a constant infusion of sodium p-aminohippurate (PAH) and inulin (IN) in isotonic saline solution was given at the rate of $0.6 \mathrm{cc}$. $/ \mathrm{min}$. during the entire observation period through a flexible intravenous catheter by means of a constant infusion pump. After three or more control urine-collection periods of approximately $30 \mathrm{~min}$ utes each, 1 to 3 liters of isotonic saline solution were administered intravenously at a rate of 13 to $56 \mathrm{cc} . / \mathrm{min}$. The administration of $\mathrm{PAH}$ and inulin was maintained throughout the saline infusion and for approximately 210 minutes thereafter. Urine was collected every $30 \mathrm{~min}$ utes by sterile urethral catheterization and the bladder rinsed with sterile distilled water. Blood samples were drawn from a peripheral vein at hourly intervals; heparin was added as an anticoagulant.

Inulin was determined by Harrison's method (7), PAH by the method described by Smith and his associates (8), chloride by the method of Van Slyke and Hiller (9), uric acid by the Benedict and Franke method (10), creatinine by the Bonsnes-Taussky method (11), sodium and potassium by a Perkin-Elmer internal standard flame photometer, plasma proteins by the copper sulfate method (12) and the hematocrit by centrifuging heparinized blood in a Wintrobe hematocrit tube for 20 minutes.

The effects of saline infusion on renal clearances were followed in 21 subjects. In addition, the protracted effects of saline infusion on urine flow and electrolyte excretion were examined in eight additional subjects without observation on renal clearances; in these subjects, the urethral catheter was removed about 200 minutes after the end of the saline infusion, and urine was collected by spontaneous voiding for 16 to 28 hours. Four subjects were given 9 to $24 \mathrm{gm}$. of sodium chloride daily, either orally or intravenously in the form of isotonic saline solu- 
tion, in addition to their dietary intake during a period of 48 to 96 hours previous to the test. Six subjects received approximately $500 \mathrm{cc}$. of a 5 per cent solution of sodium chloride at a fairly rapid rate $(24$ to $39 \mathrm{cc} . / \mathrm{min}$.) and were observed for 210 minutes after the infusion had ended.

Clearance measurements were not started until three hours after breakfast and no food or water was given throughout the period of clearance determination. The patients in whom urine excretion was followed overnight received a light supper and breakfast, with omission of salt. All fluid intake was recorded.

Inulin and PAH clearances and urine concentrations and electrolyte excretion rates have been integrated by multiplying the observed rate in each urine collection period by the elapsed time, in order to determine the mean rate per minute. Water and electrolyte recovery in the urine has been calculated as the per cent of the quantity administered, after correction for basal excretory rate. The latter has been taken as the integrated average excretion during the three control periods, except in the case of those subjects whose control urine flow exceeded $1.5 \mathrm{cc}$./min.; such subjects were usually on the descending limb of water diuresis and, on the assumption that basal urine flow could be expected to decrease to or below 1.5 $\mathrm{cc}$ //min., this figure is arbitrarily used for this correction. No method of correction for spontaneous urine output is wholly reliable and this circumstance introduces some error into all long period calculations of the return of both water and electrolytes. No correction is made for insensible water loss. In some cases the bladder was emptied immediately at the end of the saline infusion and the urine discarded; the estimated recovery of fluid in these instances is consequently somewhat lower than the true value.

Changes in hematocrit, plasma electrolyte and protein concentration are expressed as the greatest percentile change observed during the post-infusion period, relative to control values.

\section{RESULTS}

\section{Istonic Saline Solution}

A summary of pertinent data is given in Table $I$, which records averages of control data integrated over three control periods as noted above, and the average changes induced by isotonic saline solution as revealed by integrated post-infusion rates.

Urine flow, inulin, and PAH clearances. The intravenous administration of 1 to 3 liters of isotonic saline solution increased the urine flow above control rates in 90 per cent of 29 subjects examined. Except in a few instances, however, the diuresis was much less than would be expected from the same quantity of water ingested orally. This difference between saline and water diuresis in man has long been recognized (13) but it is emphasized in few recent publications. The maximal rate of urine flow in our subjects usually occurred during the latter part of the infusion period or in the first 30 minutes thereafter and was followed by a steady decline toward the control value. There was no apparent relation between the quantity of fluid given or the rate of administration and the extent of diuresis.

The saline solution had no consistent effect upon the inulin clearance in 21 subjects maintained on a ward diet, as shown by the average figures in Table I, or in four additional subjects who had been on a high salt intake previous to the saline infusion. The PAH clearance was no more markedly affected in 20 subjects. The direction of change in the two clearances coincided in only onefourth of the observations. In one subject the PAH clearance increased by 103 per cent, but it had been anomalously low in the control periods, yielding a filtration fraction of 0.38 ; here the inulin clearance remained unchanged after infusion, the filtration fraction decreasing to 0.19 . In the four subjects who had been maintained on a high salt intake, 3 liters of isotonic saline solution caused an average increase in PAH clearance of 13 per cent without appreciably changing the inulin clearance. In neither group could changes in the inulin or $\mathrm{PAH}$ clearances be correlated with changes in urine flow, with the rate or quantity of fluid administered, or with the rate of sodium or chloride excretion in the control periods.

Sodium. The most consistent effect of the administration of isotonic saline in the present studies was the increase in the excretion of sodium, which was followed in 15 subjects on the ward diet. This increased excretion was the result of an increase in concentration in the urine as well as in the rate of urine flow. Average urine sodium concentration during the 210 minute post-infusion period increased in 12 subjects, the increase averaging 25 per cent. In one subject this figure decreased while it remained unchanged in two.

Control sodium excretion on the ward diet in these subjects averaged $0.15 \mathrm{mEq} . / \mathrm{min}$. (0.075) or $13 \mathrm{gm}$. of sodium chloride per day. This figure invariably increased after isotonic saline infusion. Except in three instances the increment in sodium excretion exceeded that in chloride excretion, but the greatest difference between sodium and chlo- 
ride in favor of the former was $0.066 \mathrm{mEq} . / \mathrm{min}$. In the four subjects on a high salt diet the control urine sodium concentration averaged $180 \mathrm{mEq}$./L. In three of these this figure increased after infusion (36, 94, and 229 per cent), while in the fourth it decreased by 50 per cent (from 368 to $184 \mathrm{mEq}$./ L.). Control sodium excretion in these subjects averaged $0.326 \mathrm{mEq}$./min., equivalent to $27.4 \mathrm{gm}$. of sodium chloride per day. Sodium excretion increased after infusion in all four subjects; the average increase was equivalent to $43 \mathrm{gm}$. of sodium chloride per day.

Chloride. After saline infusion the urine chloride concentration increased in 12 and decreased in nine subjects on the ward diet, but in only one instance was the increase marked (450 per cent); the average positive change, excluding this subject, was only 14 per cent. The four subjects on a high salt intake showed an average increase of 51 per cent.

Control chloride excretion on the ward diet averaged $0.19 \mathrm{mEq} . / \mathrm{min}$., or $15.7 \mathrm{gm}$. of sodium chloride per day. This high figure probably reflects both a high dietary intake and the effects of the sodium chloride administered with the inulin and PAH. Chloride excretion increased after saline infusion in 17 subjects; the increase averaged 100 per cent; in the other four subjects it decreased by an average of 14.3 per cent, to give an average for the entire group of +59 per

TABLE I

Changes in renal function induced by the intravenous administration of isotonic saline solution to patients maintained on a regular ward diet

\begin{tabular}{|c|c|c|c|c|c|c|c|c|c|c|c|c|}
\hline \multirow[b]{2}{*}{ Subjects } & \multirow{2}{*}{$\begin{array}{l}\text { Con- } \\
\text { trol }\end{array}$} & \multirow{2}{*}{$\begin{array}{l}\mathbf{V} \\
\text { Maximal } \\
\text { post- } \\
\text { infusion }\end{array}$} & \multirow{2}{*}{\multicolumn{2}{|c|}{$\begin{array}{cc}\text { Hematocrit } \\
\text { Lowest } \\
\text { Con- } \\
\text { trol } & \begin{array}{c}\text { post- } \\
\text { infusion }\end{array}\end{array}$}} & \multicolumn{2}{|c|}{ Protein } & \multicolumn{2}{|c|}{$\mathrm{C}_{\text {IN }}$} & \multicolumn{2}{|c|}{$\mathrm{C}_{\mathrm{PAH}}$} & \multicolumn{2}{|c|}{$\mathbf{U}_{\mathbf{C l}}$} \\
\hline & & & & & $\begin{array}{c}\text { Con- } \\
\text { trol }\end{array}$ & $\begin{array}{l}\text { Dowest } \\
\text { infusion }\end{array}$ & $\underset{\text { Con- }}{\text { trol }}$ & $\begin{array}{c}\text { Post- } \\
\text { infusion }\end{array}$ & $\begin{array}{l}\text { Con- } \\
\text { trol }\end{array}$ & $\underset{\text { infusion }}{\text { Post- }}$ & $\underset{\text { trol }}{\text { Con- }}$ & 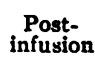 \\
\hline & \multicolumn{2}{|c|}{ cc./min. } & \multicolumn{2}{|c|}{ per cent } & \multicolumn{2}{|c|}{ stams } & \multicolumn{2}{|c|}{ cc./min. } & \multicolumn{2}{|c|}{ cc./min. } & \multicolumn{2}{|c|}{$m E q . / L$} \\
\hline $\begin{array}{l}\text { A. T. } \\
\text { M. G. } \\
\text { E. J. } \\
\text { C. P. } \\
\text { M. R. } \\
\text { J.P. } \\
\text { J. F. } \\
\text { V. H. } \\
\text { T. A. } \\
\text { T. A. } \\
\text { T. S. } \\
\text { T. S. } \\
\text { M. B. } \\
\text { G. J. } \\
\text { J. L. } \\
\text { J. T. } \\
\text { T. F. } \\
\text { J.S. } \\
\text { J.S. } \\
\text { O. B. } \\
\text { S. N. } \\
\text { J. O. } \\
\text { J. M. } \\
\text { J. S. } \\
\text { E. C. } \\
\text { M. J. } \\
\text { W. G. } \\
\text { J. M. } \\
\text { J. J. }\end{array}$ & $\begin{array}{l}7.4 \\
1.8 \\
1.3 \\
3.2 \\
3.4 \\
1.7 \\
1.4 \\
1.1 \\
2.8 \\
1.4 \\
2.2 \\
2.0 \\
4.3 \\
3.5 \\
1.0 \\
0.5 \\
1.3 \\
3.2 \\
1.2 \\
1.3 \\
1.7 \\
1.0 \\
1.1 \\
1.0 \\
0.4 \\
1.1 \\
0.8 \\
2.1 \\
0.8\end{array}$ & $\begin{array}{r}4.4 \\
20.0 \\
4.3 \\
1.5 \\
15.2 \\
2.1 \\
5.2 \\
4.6 \\
17.6 \\
10.2 \\
8.1 \\
7.3 \\
3.7 \\
5.6 \\
4.5 \\
1.2 \\
2.6 \\
6.2 \\
2.0 \\
4.8 \\
2.1 \\
3.6 \\
3.2 \\
4.1 \\
3.1 \\
4.8 \\
1.2 \\
12.3 \\
4.2\end{array}$ & $\begin{array}{l}50.5 \\
46.0 \\
47.6 \\
45.3 \\
43.9 \\
50.7 \\
45.2 \\
37.3 \\
45.2 \\
38.7 \\
44.6 \\
38.2 \\
42.9 \\
35.4 \\
45.5 \\
50.5 \\
46.5 \\
45.2 \\
51.0 \\
43.4 \\
48.8 \\
41.0 \\
49.8 \\
41.8 \\
41.3 \\
36.7 \\
38.5 \\
41.5 \\
41.8\end{array}$ & $\begin{array}{l}44.0 \\
40.2 \\
45.1 \\
45.7 \\
46.6 \\
38.1 \\
38.6 \\
36.3 \\
40.4 \\
35.2 \\
39.1 \\
34.2 \\
36.8 \\
30.7 \\
40.0 \\
46.5 \\
41.2 \\
42.8 \\
39.6 \\
36.5 \\
45.9 \\
40.7 \\
45.3 \\
36.4 \\
39.6 \\
32.6 \\
35.2 \\
39.2 \\
38.5\end{array}$ & $\begin{array}{l}5.90 \\
5.06 \\
5.15 \\
5.55 \\
5.00 \\
5.75 \\
5.35 \\
5.00 \\
5.93 \\
5.36 \\
4.64 \\
7.22 \\
5.35 \\
5.00 \\
5.35 \\
6.50 \\
5.75 \\
4.82 \\
5.35 \\
4.65 \\
5.00 \\
5.00 \\
5.20 \\
4.80 \\
5.00\end{array}$ & $\begin{array}{l}5.60 \\
4.65 \\
3.99 \\
3.90 \\
3.52 \\
4.25 \\
4.27 \\
4.10 \\
5.00 \\
3.91 \\
3.90 \\
5.36 \\
4.28 \\
4.25 \\
4.49 \\
5.55 \\
5.35 \\
4.65 \\
4.65 \\
3.90 \\
4.80 \\
4.10 \\
4.65 \\
4.27 \\
4.28\end{array}$ & $\begin{array}{l}151.7 \\
115.7 \\
181.3 \\
104.2 \\
160.5 \\
107.1 \\
115.3 \\
126.2 \\
109.0 \\
110.0 \\
119.0 \\
115.3 \\
139.8 \\
154.0 \\
118.9 \\
202.0 \\
114.2 \\
122.8 \\
100.3 \\
59.6 \\
204.0\end{array}$ & $\begin{array}{r}131.0 \\
103.0 \\
111.3 \\
101.4 \\
185.2 \\
99.0 \\
83.3 \\
125.5 \\
122.0 \\
117.2 \\
122.7 \\
122.2 \\
139.8 \\
157.6 \\
126.3 \\
149.0 \\
109.8 \\
124.4 \\
105.0 \\
71.9 \\
164.0\end{array}$ & $\begin{array}{r}536 \\
508 \\
682 \\
661 \\
586 \\
779 \\
586 \\
307 \\
833 \\
736 \\
581 \\
603 \\
609 \\
655 \\
572 \\
604 \\
525 \\
554 \\
483 \\
356 \\
1060\end{array}$ & $\begin{array}{l}644 \\
551 \\
467 \\
719 \\
610 \\
826 \\
751 \\
624 \\
847 \\
689 \\
577 \\
637 \\
623 \\
596 \\
667 \\
702 \\
524 \\
542 \\
456 \\
398 \\
905\end{array}$ & $\begin{array}{r}196 \\
247 \\
157 \\
82 \\
92 \\
96 \\
229 \\
175 \\
154 \\
105 \\
123 \\
149 \\
174 \\
125 \\
224\end{array}$ & $\begin{array}{r}217 \\
241 \\
144 \\
149 \\
108 \\
123 \\
238 \\
159 \\
147 \\
100 \\
186 \\
78 \\
220 \\
135 \\
177\end{array}$ \\
\hline Average & 1.9 & 5.2 & 43.9 & 39.7 & 5.35 & 4.47 & 125 & 124 & 610 & 636 & 138 & 157 \\
\hline $\begin{array}{c}\text { Standard } \\
\text { deviation }\end{array}$ & & 3.9 & & 3.1 & & 0.48 & & 20 & & 107 & & 51 \\
\hline Probability & & $\begin{array}{r}.001 \\
\text { Signif. }\end{array}$ & & $\begin{array}{r}.001 \\
\text { Signif. }\end{array}$ & & $\begin{array}{r}.001 \\
\text { Signif. }\end{array}$ & & $\underset{\text { Not }}{.6}$ & & $\begin{array}{c}\text { Not } \\
\text { signif. }\end{array}$ & & $\begin{array}{c}.1-.05 \\
\text { Not } \\
\text { signif. }\end{array}$ \\
\hline
\end{tabular}


TABLE I-Continued

Changes in renal function induced by the intravenous administration of isotonic saline solution to patients maintained on a regular ward diet

\begin{tabular}{|c|c|c|c|c|c|c|c|c|c|c|c|c|c|}
\hline \multirow[b]{2}{*}{ Subjects } & \multicolumn{2}{|c|}{$U_{C I V}$} & \multicolumn{2}{|c|}{$\mathrm{U}_{\mathrm{Na}}$} & \multicolumn{2}{|c|}{$\mathrm{U}_{\mathrm{Na}} \mathrm{V}$} & \multicolumn{2}{|c|}{$\mathbf{U}_{\mathbf{K}}$} & \multicolumn{2}{|c|}{$\mathbf{U K V}_{\mathbf{K}}$} & \multirow{2}{*}{\multicolumn{3}{|c|}{ Recovery in 210 minutes }} \\
\hline & $\begin{array}{c}\text { Con- } \\
\text { trol }\end{array}$ & $\begin{array}{c}\text { Post- } \\
\text { infusion }\end{array}$ & $\begin{array}{l}\text { Con- } \\
\text { trol }\end{array}$ & $\begin{array}{c}\text { Post- } \\
\text { infusion }\end{array}$ & $\begin{array}{l}\text { Con- } \\
\text { trol }\end{array}$ & $\begin{array}{c}\text { Post- } \\
\text { infusion }\end{array}$ & $\begin{array}{l}\text { Con- } \\
\text { trol }\end{array}$ & $\begin{array}{c}\text { Post- } \\
\text { infusion }\end{array}$ & $\begin{array}{l}\text { Con- } \\
\text { trol }\end{array}$ & $\begin{array}{c}\text { Post- } \\
\text { infusion }\end{array}$ & & & $\begin{array}{l}\text { Inutes } \\
\mathrm{Na}\end{array}$ \\
\hline & \multicolumn{2}{|c|}{$m E q . / m i n}$. & \multicolumn{2}{|c|}{$m E q . / L}$. & \multicolumn{2}{|c|}{$m E_{Q} / \min }$. & \multicolumn{2}{|c|}{$m E q . / L}$. & \multicolumn{2}{|c|}{$m E q . / m i n$} & \multicolumn{3}{|c|}{ per cent } \\
\hline $\begin{array}{l}\text { A. T. } \\
\text { M.G. } \\
\text { E. J. } \\
\text { C. P. } \\
\text { M. R. } \\
\text { J.P. } \\
\text { J. F. } \\
\text { V. H. } \\
\text { T. A. } \\
\text { T. A. } \\
\text { T.S. } \\
\text { T.S. } \\
\text { M. B. } \\
\text { G. J. }\end{array}$ & $\begin{array}{l}.237 \\
.230 \\
.163 \\
.297 \\
.162 \\
.222\end{array}$ & $\begin{array}{l}.500 \\
.226 \\
.258 \\
.255 \\
.115 \\
.493\end{array}$ & & & & & & & & & $\begin{array}{r}* 18.0 \\
*-3.7 \\
* 22.6 \\
*-1.4 \\
70.8 \\
9.3 \\
38.7 \\
* 6.9 \\
47.3 \\
136.5 \\
23.2 \\
24.4 \\
9.2 \\
20.5\end{array}$ & $\begin{array}{r}* 21.8 \\
*-0.3 \\
* 8.7 \\
*-6.5 \\
*-6.0 \\
25.4\end{array}$ & \\
\hline $\begin{array}{l}\text { J. L. } \\
\text { J.T. } \\
\text { J. F. } \\
\text { J.S. } \\
\text { O. B. } \\
\text { S. N. } \\
\text { J. O. } \\
\text { J. M. } \\
\text { J. S. } \\
\text { E. C. } \\
\text { M. J. } \\
\text { W.G. } \\
\text { J. M. } \\
\text { J. J. }\end{array}$ & $\begin{array}{l}.198 \\
.114 \\
.188 \\
.237 \\
.109 \\
.120 \\
.390 \\
.192 \\
.166 \\
.101 \\
.054 \\
.150 \\
.134 \\
.256 \\
.172\end{array}$ & $\begin{array}{l}.469 \\
.201 \\
.164 \\
.411 \\
.163 \\
.337 \\
.394 \\
.299 \\
.266 \\
.230 \\
.238 \\
.201 \\
.188 \\
. .458 \\
.406\end{array}$ & $\begin{array}{r}163 \\
194 \\
108 \\
77 \\
107 \\
131 \\
185 \\
177 \\
165 \\
85 \\
171 \\
155 \\
173 \\
129 \\
138\end{array}$ & $\begin{array}{l}203 \\
204 \\
128 \\
145 \\
124 \\
143 \\
214 \\
172 \\
157 \\
105 \\
234 \\
80 \\
235 \\
143 \\
151\end{array}$ & $\begin{array}{l}.165 \\
.090 \\
.129 \\
.217 \\
.126 \\
.165 \\
.222 \\
.204 \\
.179 \\
.083 \\
.075 \\
.155 \\
.132 \\
.263 \\
.107\end{array}$ & $\begin{array}{l}.434 \\
.171 \\
.150 \\
.400 \\
.186 \\
.392 \\
.360 \\
.322 \\
.280 \\
.237 \\
.286 \\
.203 \\
.200 \\
.424 \\
.353\end{array}$ & $\begin{array}{r}92 \\
101 \\
108 \\
18 \\
52 \\
46 \\
96 \\
60 \\
67 \\
72 \\
44 \\
51 \\
91 \\
24 \\
156\end{array}$ & $\begin{array}{l}38 \\
82 \\
96 \\
18 \\
43 \\
19 \\
63 \\
27 \\
25 \\
33 \\
26 \\
22 \\
63 \\
15 \\
53\end{array}$ & $\begin{array}{l}.095 \\
.046 \\
.129 \\
.052 \\
.061 \\
.057 \\
.162 \\
.070 \\
.072 \\
.069 \\
.020 \\
.050 \\
.069 \\
.049 \\
.106\end{array}$ & $\begin{array}{l}.074 \\
.068 \\
.110 \\
.051 \\
.065 \\
.050 \\
.101 \\
.051 \\
.046 \\
.071 \\
.030 \\
.057 \\
.049 \\
.035 \\
.102\end{array}$ & $\begin{array}{r}9.7 \\
9.7 \\
0 \\
35.7 \\
9.5 \\
36.0 \\
3.4 \\
22.0 \\
19.8 \\
38.7 \\
19.7 \\
31.3 \\
1.6 \\
35.2 \\
0.6\end{array}$ & $\begin{array}{r}40.2 \\
15.6 \\
-3.6 \\
27.7 \\
8.1 \\
33.5 \\
0.6 \\
14.0 \\
15.6 \\
20.9 \\
32.3 \\
6.4 \\
9.9 \\
14.9 \\
11.0\end{array}$ & $\begin{array}{r}40.0 \\
14.5 \\
3.1 \\
28.8 \\
8.9 \\
35.1 \\
29.6 \\
15.3 \\
15.8 \\
25.0 \\
37.0 \\
4.9 \\
12.3 \\
23.6 \\
14.1\end{array}$ \\
\hline Average & .185 & .294 & 144 & 163 & .154 & .293 & 72 & 41 & .074 & .064 & 24.0 & 14.0 & 17.0 \\
\hline $\begin{array}{l}\text { Standard } \\
\text { deviation }\end{array}$ & & 33 & & 83 & & 77 & & 25 & & 19 & & & \\
\hline Probability & & $\begin{array}{c}.001 \\
\text { Signif. }\end{array}$ & & $\begin{array}{l}.1-.05 \\
\text { Not } \\
\text { signif. }\end{array}$ & & Signif. & & $\begin{array}{l}\text { Signif. } \\
\text {.001 }\end{array}$ & & $\begin{array}{l}.1-.05 \\
\text { Not } \\
\text { signif. }\end{array}$ & & & \\
\hline
\end{tabular}

* Washout period during saline infusion not included.

cent. Chloride excretion in the four subjects on a high salt intake averaged $0.338 \mathrm{mEq} . / \mathrm{min}$. and increased after isotonic saline infusion by an average of 274 per cent.

Potassium. The urine potassium concentration in 15 subjects on a ward diet decreased after isotonic saline infusion in all but one subject, who showed no change. Potassium excretion was randomly affected, increasing in five instances by 3 to 50 per cent and decreasing in nine ( -4 to - 37 per cent). Urine potassium concentration likewise decreased after infusion in the four subjects on a high salt diet (average -30 per cent) but the rate of excretion changed significantly in only one (from 0.028 to $0.122 \mathrm{mEq}$./min.).
Plasma changes. Plasma and sodium chloride concentrations were changed minimally by the infusion of 1 to 3 liters of isotonic saline solution. Potassium concentration was more markedly affected, but the changes were random in direction and ranged from -10 to +32 per cent of control levels. In the four patients on a high sodium chloride intake the saline infusion increased the plasma chloride concentration by +5 to +13 per cent and the plasma sodium by 0 to +4 per cent, while the plasma potassium concentration changed by -4 to +19 per cent.

The hematocrit decreased in the majority of patients immediately after the administration of isotonic saline solution, returning toward but not 
to initial levels at the end of the observation period. The average maximal decrease was only 8 per cent. The concentration of plasma protein also decreased in all cases immediately after saline infusion, with a gradual return toward normal; the average maximal decrease was 16 per cent.

The progressive return of both hematocrit and plasma protein concentration toward control levels cannot represent solely the distribution of saline between the circulatory tree and the interstitial fluid. Isotope studies indicate that 60 per cent of plasma sodium and chloride and 140 per cent of the plasma water are exchanged with the extravascular compartment per minute in the guinea pig. In man, 78 per cent of the plasma sodium and 105 per cent of the plasma water are exchanged with extravascular sodium and water per minute (14-16). Assuming that the extracellular fluid represents 16 per cent of the body weight $(17,18), 3$ liters of saline should dilute the 11 liters of extracellular fluid in a $70 \mathrm{~kg}$. man by 21 per cent. In the light of the data cited above one would expect rapid and persistent dilution of the hematocrit and plasma protein to this extent. The facts that the maximal decrease in both values is much less and that both return toward normal before the saline is excreted (vide infra) indicate that a substantial fraction of the saline escapes from the extracellular into the intracellular compartment.

Recovery of salt and water. In the 21 subjects on the ward diet, the recovery of administered water as urine (with correction for basal flow, as noted under Methods) at the end of 210 minutes after termination of the infusion averaged only 24 per cent. In only one subject did water recovery exceed 100 per cent, while in nine recovery was less than 10 per cent. Recovery of chloride in 21 subjects averaged 14 per cent and recovery of sodium 18 per cent.

In eight subjects urine was collected for 16 to 28 hours after isotonic saline infusion, in anticipation of a possible delayed excretion of water or electrolyte. (We recognize that such recoveries, corrected as they must be for the basal excretion of urine and electrolyte, are subject to large error because of the diurnal variation in water and electrolyte excretion and other uncontrolled factors.) The calculated recovery of water, sodium and chloride decreased progressively the longer the study was carried on in four subjects, while in the other four subjects recoveries appeared to remain at fairly constant levels or to increase slightly the longer the subject was observed. However, at no time did the recovery approach the quantity of fluid or electrolyte administered.

The administration of 9 to $24 \mathrm{gm}$. of sodium chloride per day for a week previous to the experimental procedure had no effect on the immediate recovery of either water or electrolytes; the recovery of water averaged 18 per cent, of chloride 21 per cent, and of sodium 16 per cent.

\section{Hypertonic Sodium Chloride Solution}

Inulin and $P A H$ clearances. In the six subjects who received $500 \mathrm{cc}$. of 5 per cent sodium chloride solution the urine flow increased above the control level in all and reached peak levels of 2.4 to 7.3 $\mathrm{cc} . / \mathrm{min}$. The filtration rate increased in three (16, 19 , and 98 per cent) and decreased in three $(2,6$, and 7 per cent). The PAH clearance increased in five (11 to 90 per cent) and decreased in one (7 per cent).

Chloride. The urine chloride concentration increased in all, and reached values in the range of 232 to $265 \mathrm{mEq}$./L. Chloride excretion increased to the range of 0.46 to $1.58 \mathrm{mEq} . / \mathrm{min}$.

Sodium. Urine sodium concentration increased in all six subjects to levels of 216 to $265 \mathrm{mEq}$./L., while sodium excretion reached levels of 0.49 to $1.41 \mathrm{mEq} . / \mathrm{min}$. Urine concentrations of both sodium and chloride after the administration of hypertonic saline solution were always well above the plasma concentrations. Urine potassium concentration increased in some instances and decreased in others, the average of all cases being +30 per cent, while the excretion of potassium increased by an average of +82 per cent.

Since the amount of fluid administered was small ( 500 cc.) no attempt was made to estimate water recovery, but the increase in urine flow was insufficient to effect substantial recovery of water. Sodium recovery in approximately 210 minutes averaged 24 per cent and chloride recovery averaged 25 per cent, figures only moderately greater than were obtained with isotonic saline solution.

The average maximal decrease in the hematocrit was 15 per cent, in plasma protein concentration, 13 per cent, figures which are again disproportionately low considering the quantity of sodium 
chloride administered, a quantity which might be expected to effect marked hemodilution by expansion of the extracellular fluid at the expense of intracellular water.

Changes in the electrolyte composition of the plasma were, of course, more marked after hypertonic than after isotonic saline solution. The plasma chloride concentration increased by 10 to 20 per cent and the concentration of sodium by 7 to 10 per cent, while the changes in the plasma potassium concentration ranged from -19 to +36 per cent.

\section{Uric Acid/Creatinine Excretion Ratio}

In view of the possibility that adrenal cortical activity might be altered by the administration of saline, and that a change in cortical activity might be reflected in the uric acid/creatinine excretion ratio, this ratio was followed in eight subjects before and after the administration of isotonic saline, and in five subjects before and after the administration of 5 per cent saline. The changes in the ratio were, however, so slight that we do not consider them to be significant.

\section{DISCUSSION}

In contrast to the renal response observed in the dog, the intravenous administration of isotonic saline solution in quantities up to one-quarter of the extracellular fluid volume does not consistently induce a sustained increase in filtration rate or renal plasma flow in human subjects. In 11 of 21 subjects tested, the filtration rate after the infusion ended either decreased or underwent less than a 5 per cent increase. Despite the absence of a consistent increase in filtration rate, the excretion of sodium and chloride was substantially increased in nearly all subjects. There was no correlation between the changes in filtration rate and in the excretion of these electrolytes. Since the plasma concentration of sodium was not significantly altered, it must be concluded that the intravenous administration of isotonic and hypertonic saline solutions generally leads to increased sodium chloride excretion in consequence of diminished tubular reabsorption at a constant filtered load.

The effects of isotonic saline solution upon the excretion of water are difficult to evaluate. In three instances the administration of this solution led to the excretion of a urine substantially more dilute in sodium and chloride than the plasma. This anomalous response simulated the water diuresis shown by subjects who have been prehydrated with 1500 to $2000 \mathrm{cc}$. of water eight to 13 hours previous to the administration of saline, as reported by Ladd $(19,20)$ since this study was completed. On the whole, however, our subjects did not show the copious excretion of either sodium or water which Ladd reports. We are inclined to agree that the important difference between his subjects and ours lies in the quantity of water consumed the evening before the saline test, and perhaps in the speed with which this water is ingested.

The administration of 5 per cent sodium chloride solution also led to increased sodium and chloride excretion regardless of whether the filtration rate increased or not, though the recovery of water and electrolyte was not materially greater than with isotonic saline. In no instance did the urine sodium or chloride concentration fall below that of plasma in the post-infusion phase.

Wesson and his associates ( 3 ) have shown in the dog that the tubular reabsorption of sodium at a constant filtered load is increased when the extracellular fluid volume is expanded without change in electrolyte composition. Our data clearly demonstrate that in man the rapid administration of saline (though without effort to sustain the expansion of the extracellular fluid volume) has the opposite effect: namely, to reduce tubular reabsorption at essentially constant filtered loads. The conditions of our experiments are not identical with those of Wesson and his co-workers, but they are sufficiently similar to suggest that man and the dog differ not only in respect to the effects of expansion of the extracellular fluid upon the filtration rate, but also in respect to changes in tubular reabsorption at a constant filtered load. Tubular reabsorption is increased in the dog but decreased in man under these roughly parallel conditions. It seems probable, nevertheless, that the absence of an increase in filtration rate accounts for the fact that man excretes sodium chloride, no matter how administered, so much more sluggishly than does the dog.

The similarity of the response in subjects who had been maintained for several days on a high salt diet with that obtained in patients maintained on a ward diet indicates that neither the failure to obtain an increase in glomerular filtration nor the 
phenomenon of decreased tubular reabsorption of sodium after saline administration is related to the salt balance of the subject.

\section{SUM MARY}

1. The filtration rate, renal plasma flow and excretion of sodium chloride, potassium and water were followed for eight or more clearance periods (210 minutes) after the intravenous administration of isotonic sodium chloride ( 1 to 3 liters) or hypertonic sodium chloride ( $500 \mathrm{cc}$. of 5 per cent saline) solutions to subjects free of complicating diseases.

2. Neither isotonic nor hypertonic saline solution produced a consistent post-infusion increase in filtration rate or renal plasma flow. Both types of solution, however, increased sodium and chloride excretion irrespective of changes in filtration rate.

3. Whatever significance the filtration rate may have in the excretion of sodium by the human kidney, it appears that other mechanisms are capable of promoting sodium excretion by reducing tubular reabsorption at a constant filtered load.

4. In man, both isotonic and hypertonic saline solutions are retained in the body for long periods, only some 25 per cent, at best, being excreted within three and one-half hours. The recovery of administered electrolyte and water is not appreciably modified by previously loading the body with salt.

5. The human kidney differs from that of the $\operatorname{dog}$ in that isotonic and hypertonic saline solutions fail to increase the filtration rate (and renal plasma flow) consistently, a fact suggestively related to the failure of the human kidney to excrete a relatively large fraction of either solution within a few hours.

\section{REFERENCES}

1. Wesson, L. G., Jr., Anslow, W. P., Jr., and Smith, H. W., The excretion of strong electrolytes. Bull. New York Acad. Med., 1948, 24, 586.

2. Wesson, L. G., Jr., and Anslow, W. P., Jr., Excretion of sodium and water during osmotic diuresis in the dog. Am. J. Physiol., 1948, 153, 465.

3. Wesson, L. G., Jr., Anslow, W. P., Jr., Raisz, L. G., Bolomey, A. A., and Ladd, M., Effect of sustained expansion of extracellular fluid volume upon filtration rate, renal plasma flow and electrolyte and water excretion in the dog. Am. J. Physiol., 1950, $162,677$.

4. Mudge, G. H., Foulks, J., and Gilman, A., Effect of urea diuresis on renal excretion of electrolytes. Am. J. Physiol., 1949, 158, 218.

5. Ladd, M., and Raisz, L. G., Response of the normal dog to dietary sodium chloride. Am. J. Physiol., 1949, 159, 149.

6. Crawford, B., and Ludemann, H., The intravenous administration of salt solutions. In preparation.

7. Harrison, H. E., A modification of the diphenylamine method for determination of inulin. Proc. Soc. Exper. Biol. \& Med., 1942, 49, 111.

8. Smith, H. W., Finkelstein, N., Aliminosa, L., Crawford, B., and Graber, M., The renal clearances of substituted hippuric acid derivatives and other aromatic acids in dog and man. J. Clin. Invest., 1945, 24, 388.

9. Van Slyke, D. D., and Hiller, A., Application of Sendroy's iodometric chloride titration to proteincontaining fluids. J. Biol. Chem., 1947, 167, 107.

10. Benedict, S. R., and Franke, E., A method for the direct determination of uric acid in urine. J. Biol. Chem., 1922, 52, 387.

11. Bonsnes, R. W., and Taussky, H. H., On the colorimetric determination of creatinine by the Jaffe reaction. J. Biol. Chem., 1945, 158, 581.

12. Phillips, R. A., Van Slyke, D. D., Hamilton, P. B., Dole, V. P., Emerson, K., Jr., and Archibald, R. M., Measurement of specific gravities of whole blood and plasma by standard copper sulfate solutions. J. Biol. Chem., 1950, 183, 305.

13. Smith, H. W., The Physiology of the Kidney. Oxford University Press, New York, 1937.

14. Flexner, L. B., Gellhorn, A., and Merrell, M., Studies on rates of exchange of substances between the blood and extravascular fluid; exchange of water in the guinea pig. J. Biol. Chem., 1942, 144, 35.

15. Merrell, M., Gellhorn, A., and Flexner, L. B., Studies on rates of exchange of substances between the blood and extravascular fluid. II. The exchange of sodium in the guinea pig. J. Biol. Chem., 1944, 153, 83.

16. Flexner, L. B., Cowie, D. B., and Vosburgh, G. J., Studies on capillary permeability with tracer substances. Conference on biological applications of nuclear physics. Technical Information Division, ORE, U. S. A. E. C., Oak Ridge, Tennessee, 1948, p. 81.

17. Schwartz, I. L., Schachter, D., and Freinkel, N., The measurement of extracellular fluid in man by means of a constant infusion technique. J. Clin. Invest., 1949, 28, 1117.

18. Schwartz, I. L., Breed, E. S., and Maxwell, M. H., Comparison of the volume of distribution, renal and extrarenal clearances of inulin and mannitol in man. J. Clin. Invest., 1950, 29, 517.

19. Ladd, M., The effect of prehydration on the response to saline infusion in man. J. Appl. Physiol., 1950, 3, 379.

20. Ladd, M., The effect of prehydration upon the renal excretion of sodium in man. J. Appl. Physiol., 1950, 3,603 . 